\title{
Enhancement Learning Outcome of Science in Elementary Students by Cooperative Learning and Logical Thinking Method
}

\author{
Sita Ratnaningsih ${ }^{\mathrm{a}}$, Wit Laili Darmayanti ${ }^{\mathrm{b}}$ \\ ${ }^{a}$ Syarif Hidayatullah State Islamic University Jakarta, Jl. Ir. H. Djuanda 95, Ciputat, Indonesia \\ bJakarta State University, Jl. Rawamangun Muka, Jakarta, Indonesia \\ Corresponding e-mail: $\underline{\text { sita@uinjkt.ac.id }}$
}

\begin{abstract}
Natural Science Learning is a very crucial thing, at this time the results of science learning in the primary schools in Indonesia on a national average is still low. Though studying science since elementary school is a very important. The purpose in this study was to investigate the influence of cooperative learning method and logical thinking toward the ability in learning outcomes science $4^{\text {th }}$ grade students. This study was conducted on $4^{\text {th }}$ grade students of Elementary School, by taking 68 samples. Data were acquired using two-way Varian analysis test (ANOVA) utilizing treatment by level $2 \times 2$ design. The result study showed that: (1) the learning outcomes of student's cooperative learning method group investigation techniques is not higher than that of using think pair share techniques, (2) there is interaction correlation between students' cooperative learning methods and their logical thinking, (3) learning outcomes students with higher logical thinking using cooperative learning method investigation group techniques is higher than using cooperative learning method think pair share techniques, (4) learning outcomes students with lower logical thinking using cooperative learning method think pair share techniques is higher than using cooperative learning method investigation group techniques. The results of this study illustrate that using cooperative learning method by considering their logical thinking can increase students' ability in learning outcome science.
\end{abstract}

Keywords: cooperative learning methods, logical thinking, enhancement learning outcomes, elementary students

\section{INTRODUCTION}

Science learning results in elementary school is low. Though learning science since elementary school is important. Tracey et all (2012) stated that teaching and learning in elementary level have to provide an interactive, inspiring, joyful, challenging, motivating students to be actively involved, and give proper chance for students to be initiative, creative, and has self-independency in improving their talent, physical and psychological growth. Therefore, learning process in elementary school should give more attention on learning based on experience, interaction with the objects, phenomenon, and environment. It is hoped to be able to develop aspects of learning according to the proper process.

According to Wina Sanjaya (2011) plenty of teachers are still in misperception about mastering the material in which they still think they are the center of learning and mastering whole material. In schools, there are teachers that do not check whether students have understood the material or not. As the result students have low motivation to learn about the material.

Teachers' misunderstanding of the situation and condition will lead to the students' boredom related to the material. Some students will feel bored and tend to do other activities that are not related to the teaching process. It means that there is no sense of responsibility between the students and the learning process. The material will not be delivered properly and the result the learning goals will not be achieved as well.

In schools there many students that feel bored and stress during the learning process and tend to be ignored without any solution. This condition is the 
result of teacher-centered used in teaching learning process, therefore the students are not able to be a problem-solver.

Based on facts, students are expected to design their own learning process based on their experiences, interaction with objects, phenomenon, and environment, in order to be pious, smart, and have good behavior. As explained by Anderson and Krathwohl that there are four types of knowledge: 1) Factual, 2) Conceptual, 3) Procedural, 4) Metacognitive (2001), followed by the explanation of Mishra that "learning is a relatively permanent change in behavior brought about by experience" (2009) In other words process of learning is the result of actual experiences that focus on the permanent change of behavior.

In addition, students should continuosly works in group to solve complex problems. In line with that, Slavin (2005) stated that small-group learning can give positive impact to the learning achievements. By cooperative learning, students are expected to have significance improvement in their learning process. Different viewpoints have been brought in connection with the mixture of the group's members, from the viewpoint of some specialties like race, language, culture, sentimental relations; degree of students agreement and educational achievement, which most of them (the viewpoint) put emphasis on heterogeneous of cooperative group's members. Kagan`s research indicated that most favourite number for the group is four (Kagan, 1998; Morales, 2009; Meerah, 2010). Harvard University's researches indicate that when each of the members perform their duties before the entrance into the class, learning groups will be effective. Of course this matter depends on the degree of responsibility of the group's members (Gardner \& Jewler, 2000). The research directly of implicitly have emphasized this matter that cooperative learning by considering the their logical thinking can increase toward ability in learning outcome, that is different with the results of Keramati 's research (2007) indicated that cooperative learning has had an influence on development of social skills of students in grade five. Masoud, et.al (2011) reported that, the results indicate that cooperative learning method in comparison with traditional method has more influence on social skills of students. Tolmie et al. (2009) observed many noticeable improvements of social relations, in their own researches on the heading of "The social effects of cooperative learning in the elementary schools". In the connection the effects of cooperative learning on social and psychological traits of undergraduate in fundamental mathematics course, Kocak (2008) understood that cooperative learning is effective in reducing the levels of loneliness and social anxiety and increasing the levels of happiness among the participant. The finding of Erdem's study (2009) indicate that cooperative learning in the group work enabled distributing the tasks within the group, solving the problems occurred friends by talking and negotiating, finding chance to talk, interact with classmate, and using the time effectively. According to Wendy (2007) what was said, the present study planned to study the effectiveness of cooperative learning methods and logical thinking to natural science learning outcomes at elementary students. Related with natural sciences, there are two proper cooperative learning process that can be applied, Group Investigation (GI) and Think Pair Share (TPS).

According to Sharan (2005) that Group Investigation is a technique that can increase student activity in the discovery of knowledge. Trianto (2011), also explained that Group Investigation (GI) is suitable for an integrated study project that focuses on analysis and synthesis of information in order to solve problems.

Anita Lie (2004) stated, Think Pair Share is a technique that makes students to work individually or in group. In other word, Think Pair Share (TPS) let all students to have chances in think and express their ideas to the others in more chances. This is in accordance with the results of research Khotiyal (2013) which concluded that the think pair share can increase student learning activities as much as $83 \%$ than before. The study was supported by the results of research Diane (2007) who stated that students who learn to use TPS techniques will be encouraged to read more, then the intensity of reading students will be more increased. Meanwhile, according to Ivy, et.all (2010), it was concluded in their research that group investigation technique did increase student activity in learning process, but did not affect student learning outcomes. Therefore, students can express and show their active participation to others in better way compare to classical learning process.

Both techniques, Think Pair Share and Group Investigation, require good reasoning skill of the students. Reasoning skill is a process to think logically and systematically about the empirical facts that can be observed in order to have a conclusion, in this case is knowledge. Based on the explanation above, the aim of this research was known whether cooperative learning method (GI and TPS) has positive effect with logical thinking in learning natural sciences. 


\section{METHODS}

The method of the research was experimental research with treatment by level 2 × 2 design. Cash, Philip, et.all (2016) experimental research is a research that is conducted in order to find the effect of a treatment to a control condition. In this research treatment is used to examine the effect of two variables, treatment is two cooperative learning techniques, GI and TPS, which are symbolized with $\mathrm{X}_{1}$ and moderator variable, low level logical thinking skill and high level logical thinking skills, which are symbolized with $\mathrm{X}_{2}$. The bound variable is natural sciences learning result which symbolized with $\mathrm{Y}$.

The treatment is given to two groups. The first one is high-level logical thinking skill group that is treated with Group Investigation technique. The second group is low-level logical thinking skill group that is treated with Think Pair Share technique.

During the learning process, the researcher collects all necessary data related with the research as many as possible. It is hoped that the data are accurate.

\section{RESULTS AND DISCUSSION}

Before analyzing the data with two way analysis of variance (ANOVA) there are two pre-required tests conducted, normality and homogeneity. Liliefors test is used to check normality, whether the data have been distributed normally or not. The summary of the normality test of natural science score is shown as follow in table 1:

Table 1. Test of Normality Result

\begin{tabular}{lllll}
\hline Group & $\mathrm{N}$ & $\mathrm{L}_{\mathrm{ob}}$ & $\mathrm{L}_{\text {table }}$ & Des. \\
\hline $\mathrm{A}_{1}$ & 16 & 0,141 & 0,213 & Normal \\
$\mathrm{A}_{2}$ & 16 & 0,104 & 0,213 & Normal \\
$\mathrm{B}_{1}$ & 16 & 0,184 & 0,213 & Normal \\
$\mathrm{B}_{2}$ & 16 & 0,120 & 0,213 & Normal \\
$\mathrm{A}_{1} \mathrm{~B}_{1}$ & 8 & 0,141 & 0,285 & Normal \\
$\mathrm{A}_{1} \mathrm{~B}_{2}$ & 8 & 0,098 & 0,285 & Normal \\
$\mathrm{A}_{2} \mathrm{~B}_{1}$ & 8 & 0,221 & 0,285 & Normal \\
$\mathrm{A}_{2} \mathrm{~B}_{2}$ & 8 & 0,140 & 0,285 & Normal \\
\hline
\end{tabular}

Bartlett test is used to test the homogeneity, to check whether the data is homogeneous or not. The significance level of the data is $\alpha=0.05$. The result of homogeneity test is as followed in table 2 .
Table 2. The Result of Bartlett Test $\alpha=0,05$

\begin{tabular}{|c|c|c|c|}
\hline Group & $\chi_{{ }_{\mathrm{obb}}}$ & $\chi_{2}$ & Des \\
\hline $\mathrm{A}_{1}$ and $\mathrm{A}_{2}$ & 0,380 & 5,991 & $\begin{array}{l}\text { Homoge } \\
n\end{array}$ \\
\hline $\mathrm{B}_{1}$ and $\mathrm{B}_{2}$ & - & 5,991 & $\begin{array}{l}\text { Homoge } \\
\mathrm{n}\end{array}$ \\
\hline $\begin{array}{l}\mathrm{A}_{1} \mathrm{~B}_{1}, \quad \mathrm{~A}_{1} \mathrm{~B}_{2}, \quad \mathrm{~A}_{2} \mathrm{~B}_{1}, \quad \& \\
\mathrm{~A}_{2} \mathrm{~B}_{2}\end{array}$ & 2,772 & 3,841 & $\begin{array}{l}\text { Homoge } \\
\mathrm{n}\end{array}$ \\
\hline
\end{tabular}

As the data are distributed normally and considered as homogeneous, then all of the requirements for ANOVA have been fulfilled. The test of hypothesis used ANOVA (Two Ways Analysis of Variance) which is used to check the hypothesis of average between two samples with Treatment by Level $2 \times 2$ design.

The result of ANOVA $2 \times 2$ is shown in the table 3 as follow:

Table 3. The Result of ANOVA $2 \times 2$

\begin{tabular}{|c|c|c|c|c|c|c|}
\hline \multirow{4}{*}{$\begin{array}{l}\text { Source } \\
\text { of } \\
\text { Variati } \\
\text { on }\end{array}$} & \multirow{4}{*}{$\begin{array}{l}\text { Sum } \\
\text { of } \\
\text { Squar } \\
\text { es }\end{array}$} & \multirow{4}{*}{$\begin{array}{l}\text { Degr } \\
\text { ee of } \\
\text { Freed } \\
\text { om }\end{array}$} & \multirow{4}{*}{$\begin{array}{l}\text { Mean } \\
\text { of } \\
\text { Squar } \\
\text { es }\end{array}$} & \multirow[t]{4}{*}{$\mathrm{F}_{\mathrm{ob}}$} & \multicolumn{2}{|c|}{$\mathrm{F}$ table } \\
\hline & & & & & $\alpha=$ & $\alpha=$ \\
\hline & & & & & 0.0 & 0.0 \\
\hline & & & & & 5 & 1 \\
\hline Within & 2,53 & 1 & 2,53 & 0,05 & 4,1 & 7,4 \\
\hline A & & & & $*$ & 5 & 9 \\
\hline Within & 205,0 & 1 & 205,0 & 3,93 & 4,1 & 7,4 \\
\hline B & 3 & & 3 & $*$ & 5 & 9 \\
\hline Interact & 371,2 & 1 & 371,2 & 7,12 & 4,1 & 7,4 \\
\hline $\begin{array}{l}\text { ion } \mathrm{A} x \\
\mathrm{~B}\end{array}$ & 9 & & 9 & * & 5 & 9 \\
\hline Within & $\begin{array}{l}1460, \\
39\end{array}$ & 28 & 52,16 & - & - & - \\
\hline Total & $\begin{array}{l}2039, \\
22\end{array}$ & 31 & - & - & - & - \\
\hline
\end{tabular}

Based on the previous study, researcher also proved that by applying cooperative technique Group Investigation and Think Pair Share with logical thinking skill can improve the result of natural science course within the topic of senses in grade $4^{\text {th }}$ of Elementary School significantly.

The result of the research, by applying cooperative technique with logical thinking skill are as follows: (1) Boosting the students' confidence, (2) Students are more enthusiastic with the course, (3) improve students' curiosity to the courses, (4) Students are able to actively involved in learning and showing their understanding in the previous courses.

While specific result findings are as follow: (1) The result of learning natural sciences between group 
treated with Group Investigation and Think Pair Share is tend to be in same level, (2) There is an interaction effect between cooperative learning method with logical thinking skill to the result of learning natural sciences, (3) Group Investigation cooperative technique shows better significance than Think Pair Share to the students with high-level logical thinking skill, (4) Think Pair Share cooperative technique shows better significance than Group Investigation to the students with low-level logical thinking skill. One of the important points than need to be focused on and able to be focused on is TPS. It is important, as students are expected to be bright academically and religiously and also have good characters.

Cooperative learning technique, GI and TPS, is able to improve the quality of natural sciences learning. Generally it can optimized learning process by make students to apply their understanding in teamwork. It also improves students' creativity in acquiring knowledge by exploration, experimentation, and searching from various sources related with the topic of human senses.

Logical thinking skill of the students also gives great contribution in learning natural sciences. Based on the data found, students with high-level logical thinking skill learning method have better result when teach with GI. While low-level logical thinking skill students show better result of learning when teach with TPS technique.

Cooperative learning method, both GI and TPS, is designed to give effect to the interaction pattern between students. Its purpose is to improve the academic understanding of the students by make the students actively involved in learning, exploring the curiosity with the related learning topic and checking the understanding of the students related with the topic. The results of the technique are sharing, asking questions, explaining or expressing ideas, respecting others' opinion, work in group or individual, improving natural sciences learning result, cognitive aspect, accountability aspect, psychomotor aspect, and social aspect that can create qualified students.

\section{CONCLUSIONS}

Based on the result of data analysis and observation, there are some conclusions can be made; (1) Cooperative learning method, Group Investigation and Think Pair Share, in natural sciences course for grade IV at the elementary school with the learning topic human senses is improved. It can be seen from the improvement of formative test result, 77.24\%, based on the pre- and post- test, (2) Cooperative method and logical thinking skill have significant interaction, (3) Group Investigation cooperative technique shows better significance than Think Pair Share to the students with high-level logical thinking skill, (4) Think Pair Share cooperative technique shows better significance than Group Investigation to the students with low-level logical thinking skill.

\section{ACKNOWLEDGEMENTS}

Researchers are grateful to principals, teachers and students at school at the research site. Thank you also to the Faculty of Education Sciences State Islamic University Jakarta and the State University of Jakarta which has provided a lot of encouragement in the process of this research.

\section{REFERENCES}

Anderson, W., David, R., Krathwohl. (2001). A Taxonomy For Learning and Assessing a Revision of Bloom's Taxonomy of Educational Objective. New York: David McKay Company.

Carss, W. D., (2007) The Effects of Using Think-Pair-Share during Guided Reading Lessons. New Zealand: Research Commons at the University of Waikato.

Cash, P., et.all. (2016). "Experimental Design Research: Approaches, Perspectives, Applications" Springer International.

Erdem, A. (2009). Preservice Teachers` Attitudes Toward Cooperative Learning in Mathematics Course. Procedia Social and Behavioral Science, 1, 1688-1672.

Gardner, j., Jewler (2000). Your College Experience: Strategies for Success. U.S.A: Wadswort Publishing Company.

Hall T. E., Mayer, A. (2012). Universal Design for Learning in the Classroom : Practical Applications, New York, United Stated: Guildford Publication.

Kagan, S. (1998). Cooperative Learning. University of California.

Keramati, M. (2007). The Effect Cooperative Learning on Development of Social Skills and Math Achievement. Journal of psychology and Education, 37(1), 39-55.

Kocak, R. (2008). The Effect of Cooperative Learning on Psychological and Social Traits Amomg Undergraduate Students. Social Behavior and Personality, 36(6), 771782.

Kothiyal, A. (2013). Effect of think-pair-share in a large CS1 class: $83 \%$ sustained engagement. Interdisciplinary programme in Educational Technology, Mumbai, India. New York: The ninth annual international ACM conference on International computing education research.

Lavasani, M. G., Afzali, L., Borhanzadeh, S., Afzali, F., Davoodi, M. (2011). The Effect of Cooperative Learning on the Social Skills of First Grade Elementary School Girls. Procedia Social and Behavioral Sciences, 15, 1802-1805. 
Lie, A. (2004). Cooperative Learning: Mempraktikkan Cooperative Lerning di Ruang-Ruang Kelas. Jakarta: Grasindo.

Morales, R. (2009). Towards an Intelligent Environment for Distance Learning. World Journal on Educational Technology, 1(2), 110-117.

Robert E. Slavin, (2005). Cooperative Learning Teori, Riset dan Praktik. Nusa Media: Bandung.

Sanjaya, W. (2011). Strategi Pembelajaran Berorientasi Standar Proses Pendidikan. Jakarta: Kencana Prenada Media.

Sharan, Y. Enriching the Group and Investigation in the Intercultural Classroom. European Journal of Intercultural studies (Published by $T \& F$ for the International Association for Intercultural Education (IAIE), 2, 28.

Tolmie A. K., Topping, K. J., Christic, D., Danaldson, C., Howe, C., Jessiman, E., Livingston, K., Thurston, A. (2010) Social Effects of Collaborative Learning in Primary Schools. Learning and Instruction, 20 (3), 177 191.

Triyanto. (2011). Model-Model Pembelajaran Inovatif Berorientasi Konstruktivis. Jakarta: Prestasi Pustaka 